\title{
RADICALISM PREVENTION MOVEMENT: RELIGIOUS MANIFESTATION OF SHOLAWAT COMMUNITIES IN THE MATARAMAN
}

\author{
A. Jauhar Fuad \\ Institut Agama Islam Tribakti Kediri Indonesia \\ Email:info.ajauharfuad@gmail.com
}

\section{Abstract:}

Religious traditions become a form of community religiosity. One's religious attitude can be manifested in religious forms and actions through religious rituals such as prayer, fasting, zakat, pilgrimage, and other rituals such as tahlil, istighasha, and salawat. Public openness to religious traditions will close the space for radicalization. The research method uses a qualitative approach with data collection techniques, interviews, documentation and focus group discussion. The findings of this study: first, the salawat council becomes a forum for people who have a spirit of religiosity in carrying out religious traditions. The development of salawat assemblies in the Mataraman region is quite a lot, but there are salawat assemblies having affiliations with FPI and defend against HTI. Second, the salawat council's existence received a response from Gus (young Kyai) who then brought the salawat council as a counterweight to the previous assembly. Its presence becomes a choice for the people in neutralizing radical understanding. As the community's religious universe grows, it needs an assembly leading to Islam's concept wasathiyah.

Tradisi keagamaan menjadi wujud dari religiusitas masayarakat. Sikap religiusitas seseorang dapat diwujudkan dalam bentuk dan tindakan keagamaan melalui ritual-ritual kegamaan seperti, salat, puasa, zakat, haji, dan ritual lain seperti tahlil, istighasha, dan salawat. Keterbukaan masyarakat pada tradisi agama akan menutup ruang gerak radikalisasi. Metode penelitian ini menggunakan pendekatan kualitatif dengan teknik pengumpulan data, wawancara, dokumentasi 
dan FGD. Temuan penelitian ini: pertama, majelis salawat menjadi wadah bagi masyarakat yang mimiliki spirit religiusitas dalam menjalankan tradisi keagamaan. Perkembangan majelis salawat di wilayah Mataraman cukup banyak, akan tetapi ada majelis salawat yang memiliki afiliasi dengan FPI dan melakukan pembelaan terhadap HTI. Kedua, keberadaan majelis salawat tersebut mendapat respon dari Gus (kyai muda) yang kemudian memunculkan majelis salawat sebagai penyeimbang majelis sebelumnya. Kehadirannya menjadi pilihan bagi umat dalam menetralisir paham radikal. Seiring meningkatnya semangat keagamaan masyarakat, maka dibutuhkan majelis yang dapat mengarahkan pada konsep Islam wasatiyah.

Keywords: radicalism prevention; religious tradition; spirit of religiosity

\section{Introduction}

Religiosity belongs to the scope of psychology. Psychological study demonstrates that religious beliefs and practices are associated with greater life satisfaction, happiness, positive affect and increased morale (Koenig and Larson, 2001). Studies also proved the negative relationship between religiosity and juvenile delinquency (Aviyah and Farid, 2014; Nisya and Sofiah, 2012); and a negative relationship between religiosity and the lifestyle of hedonism (Saputri and Rachmatan, 2017). Other findings indicate no relationship between religiosity and attitudes toward terror behavior in prisoners of terrorism cases in Indonesia (Pertiwi and Chrisharyanto, 2016). Psychologists find special contributions from religion to health (Hill and Pargament, 2016). The results of these studies indicate that religiosity has a positive impact on individual behavior.

Religiosity has been shown to have a positive effect on individual mental health. Yet, the research evidence also seems to indicate that religiosity affects individuals negatively. The role of religion is paradoxical, it can lead to prejudice and can also lead to prejudice. The effect of religiosity on prejudices seems to indicate its negative role towards individuals (Pargament 1999) since religiosity tends to prejudice (Hood et al., 2009). This attitude will lead to prejudice to call oneself the most righteous while the other is wrong. This religious attitude is based on a religious understanding that tends to fundamentalism and leads to radicalism.

In the context of radicalism in Indonesia, people relate it to the Islamic Defenders Front (FPI) and Hizbu Tahrir Indonesia (HTI). The Islamic Defenders 
Front from the Pancasila perspective and the 1945 constitution can potentially undermine the Republic of Indonesia's ideological unity with Pancasila (Indra, 2017). FPI often causes shock to many people, especially through their radical actions in applying "amar ma'ruf nahi munkar" or enjoining good and forbidding wrong. The radical actions taken by the FPI have caused fear, even violated human rights (HAM) for some members of the community (Syaefudin, 2014). FPI is an Islamic organization that often appears in public with a violent face (Mubarok, 2010). While, the other side of FPI is not a radical Islamic fundamentalist movement with a high commitment to fight for Islam and aspires to establish an Islamic state (Al-Zastrouw, 2006).

Hizbut Tahrir Indonesia (HTI) is considered by the government to have deviated from the Pancasila ideology and endangered the nation's integrity or NKRI (Mahdi 2017). HTI is considered a nonviolent organization, although moving peacefully, this organization is considered radical, difficult to detect and dangerous. It structurally and systematically infiltrate the thinking of the formation of the Caliphate and the rejection of democracy, the ideology of the Pancasila, the 1945 Constitution, NKRI and the principle of unity in diversity "Bhinneka Tunggal Ika" (Rizki, 2018). Both FPI and HTI entered fundamentalist and radical organizations.

The issue of radicalism is fundamental in the life of the nation and state in Indonesia. Several groups identified as spreading radical notions have received attention from the government and society in general. The issue of radicalism also received serious attention from Gus (young Kyai) community in Mataraman. They consider radicalism to be a shared responsibility of all components of the nation, because radicalism can threaten the integrity of the Republic of Indonesia and the integrity of religious life.

The involvement of FPI sympathizers and ex-HTI activities carried out religious traditions similar to An-Nahdiyin such as tahlilan, istihgasha and salawatan. A study showed that not all types of religiosity have a buffer effect on deviations if a person's diversity is instrumental (i.e., extrinsic) (Klanjšek et al., 2012). FPI and ex-HTI in understanding diversity are more likely to be formalistic, without seeing religion as a moral message for the people's benefit. They also assume that the truth of religion belongs only to the group, others are mistaken.

FPI and ex-HTI sympathizers are spread throughout Indonesia, including in the Mataraman region (Kediri city, Kediri regency and Nganjuk regency) (Fuad 2019; Fuad and Susilo 2019; Mahzumi and Fuad 2019). Some of them 
are members of the rotib and salawat assemblies. The leadership of the assembly has a close relationship with FPI, especially Habib Riziq Sihab

Assembly rotib and salawat are also from Nahdiyin circles. In the assembly there were many alumni from large Islamic boarding schools such as Lirboyo, Ploso and Mojosari. Besides, there are also Gus as their members. Even every religious lecture activity is delivered by the NU clerics.

The assembly of rotib and salawat received a response with the birth of the Pro Salawat Assembly (PROSHO). The emergence of PROSHO was as a form of anxiety over the reality of diversity in society, which easily blames other groups, especially when those who are blamed are figures of Nahdatul Ulama whose ideas often conflict with FPI and ex-HTI. This paper tries to explain the salawat council's relationship in building awareness about religiosity as a preventive measure of radicalization in the Mataraman Region.

\section{Majlis Rotib and Salawat}

The Rotib and Salawat Majlis (ROSHO) was originally only a rotib chain (Al Atthos and Al Haddad) at Bayu's house in Kras, Kediri Regency. However, due to the increasing number of worshipers, Alhabib Husein Ba'abud (this routine initiator) was made into the assembly, with the advice and guidance from Alhabib Alwy Ba'agil from Ketapang Madura. This assembly is getting bigger with more jama'ah members, starting from many requests from the congregation to be occupied. From there, they began to establish and embrace Habaib, Masyayikh, Ulama, Umaro '(officials) and other assemblies to jointly syi'ar fi sabilillah invite the community and young people to participate in the assembly.

This assembly was well received by the community and Islamic boarding schools, for example Lirboyo Kediri, Al Ishlah, Alfalah Ploso, Mambaul Hikam Mantenan Blitar, etc. The assembly became large with its member reaching thousands or even tens of thousands. They began to expand to other areas such as Nganjuk, Blitar, Tulungagung, Trenggalek, Madiun, Ponorogo, even to Pacitan. They are consistent and always maintain amaliyah the expert of sunnah wal jama'ah such as salawat, rotib, yasinan, tahlilan, manaqib, and others. The name of the assembly was often abbreviated by Alhabib Husein Ba'abud by the name of the assembly "ROSHO" which means rotib and salawat.The ROSHO assembly was inspired by Habib Syekh Abdul Qodir Assegaf and his Ahbabul Musthof assembly. 
At present, it covers not fewer than 300 hadroh groups, all groups are located in Kediri and are under the auspices of the ROSHO assembly and it involves 15,000 members or beloved Bolo ROSHO members. The object of Bolo ROSHO is actually "youth far from religion". They also have future aspirations, namely providing social education, religion, and health facilities under the auspices of the ROSHO assembly foundation.

The profile of Habib Husen represents a unique character. He often fought his opinion with NU's opponents. Habib Husein goes more to NU opponents. ROSHO activists are partly FPI and NU. ROSHO's appearance by Habib Husain was exquisite, with very gentle people. Habib Husain was too absorbed in the news of social media which cornered NU making NU friends uncomfortable. His communication style is good, respectful, but in social media it becomes different. Habib Husain wanted to establish FPI in Kediri Raya, but it is not possible, because of the situation. Then he moved to establish a prayer room assembly, which was important to convey FPI's ideas and thoughts (Dafit Fuadi, FGD. November 19, 2018).

From the beginning Habib Husein had a close relationship with Habib Riziq (Arif Jauhari, FGD. September 10, 2018). Habib Husen's closeness with FPI influenced the mindset in social media and its interaction with other groups that were not in line with FPI's thinking. The rotib and salawat assemblies were also influenced by FPI's ideas. ROSHO's closeness with FPI gave rise to a new assembly called PROSHO.

FPI supports the call and advice of Al Qaidah leader Sheikh Imam Az Zahowahiri. All components of Al-Qaeda jihad, both Sheikh Muhammad Al Jaulani's forces in Syria and Sheikh Abu Bakr Al Baghdadi's forces in Iraq, as well as other components were brothers and sisters with all Mujahid Islam throughout the world to do jihad in Syria, Iraq, Palestine and other oppressed Islamic countries (Dewan Pimpinan Pusat Front Pembela Islam, 2014). The above statement indicates a close relationship between FPI and radical groups in the Middle East.

\section{Majlis Pro Salawat (Mas Prosho)}

Nadirin (Editor in Chief of the Mihrom Bulletin Stonogedong Mosque, Kediri City) established the assembly of Pro Salawat started since the meeting of Santri Nusantara in Trengggalek. At that time he was a speaker, Fan Rasip talked about the radicalism of the international level. After that there was a desire to continue discussing the issue of diversity (Nadirin, FGD. October 
10, 2018). Then, the Gus gathered, the themes discussed flow as they are. The gathering event is interspersed by cutting the butter and cooking together and continuing with eating together (Anang Darunajah, FGD. October 10, 2018).

Gus Nasih Mojosari said that the jamaah was originated from the ROSHO case initiated by Gus Halim Mojosari and Habib Husain" (Nasih, FGD, October 10,2018). There are concerns in the salawat assemblies inspired by the Mojosari Islamic boarding school, Kyai Tohah, Kyai Muh, and his rivals (Anang Darunajah, FGD. October 10, 2018). Aqil Fikri began to initiate a gathering forum between Gus since it is rare to meet and rarely discuss pesantren, about NU, about the state, others, which has become symptomatic (Aqil Fikri, interview. June 10, 2018).

Aqil Fikri argued that Indonesia's strength was in the hands of the TNI and NU. TNI as a military force while NU is a civilian force. NU's strength is in Islamic boarding schools, especially in the Mataraman region. In the context of looking at radicalism, not only in big cities but it has already entered the village; therefore the pesantren must be strong. Gus Atok and Gus Abid are the leaders in Mataraman region. If they do not communicate from the beginning, they will be cut off from this problem. The Gus have an awareness of the dangers of radical understanding related to the nation's continuity of life, hasten and understand ahlu sunnah wal jamah an Nahdiyah. However, they do not have collective awareness as part of the form of thoughts, attitudes and actions in addressing radicalism in the Mataraman region.

Islamic boarding schools are the most immediate guardian in addressing the issue of radicalism. Several groups are trying to overthrow NU, if they want to overthrow NU, they have to break down the pesantren. NU is the pillar of the state. This effort has been around since the 2000s. Based on internal findings, there has been a movement to change the pesantren's paradigm to change its character and culture. The network of dividing pesantren has also been seen as a dangerous threat since NU's strength is in the pesantren. To win NU, the pesantren must be broken down. Accordingly, Gus Dur in 2009 made a network of village kiai, apparently this was the answer to the effort. Abdurrahman indicated that there were movements in that era (Aqil Fikri, Interview. June 10, 2018).

Assembly Pro Salawat aims to build a shared perception, togetherness, and solidarity between fellow Gus. The Gus will now become leaders within the next ten years. They are the owners of large Islamic boarding schools in the Mataraman region. Their existence has an important role in the scientific 
hierarchy, starting from large pesantren, small pesantren, mosques, mushalla, madrasah diniyah, TPQ, and majelis ta'lim in the community.

Aqil Fikri always reminded to take care of the madrasa, mosque, and the school of madrasa diniyah as pesantren and NU become the Indonesian power (Aqil Fikri, Interview. June 10, 2018). This statement explains the reaffirmation of Gus from Lirboyo, Plosa, Mojosari and others. The large Islamic boarding schools need to be closer to the alumni who have small Islamic boarding schools, madrasas, and mosques to revive them.

PROSHO's existence cannot be released from other networks, such as the assembly of Terong Gosong pioneered by Gus Yahya. In other words, PROSHO is established from the discussion of the Terong Gosong assembly at the level of ideas and thoughts. The PROSHO committee does not have links with other organizations. Both at the local and national level. They move to the cultural area of the pesantren community in the Mataraman area. The cultural movement has an important role in stemming the flow of radicalism as it happened in Sukoharjo (Fuad, 2018).

The relationship between PROSHO majlis and several boarding schools also becomes the key to the assembly's dynamic. The elderly of Kyai can receive the concepts and ideas conveyed in the assembly. In this case, even silence can be interpreted as an agreement (Nadirin, FGD. October 10, 2018). PROSHO has a relationship with assembly Rotib and Salawat (ROSHO). However, ROSHO is rejected because the fikh, harokah and siyasah are not the same (Arif Jauhari, FGD. September 10, 2018).

The concern on radicalism began since many graduates of Islamic boarding schools participating in groups with radical ideology. Ideologically they join a radical group, then they are not accommodated in the jamiyah. Surely they were drawn towards radical groups (Arif Jauhari, FGD. September 10, 2018). Through PROSHO, all alumni of Islamic boarding schools can see radicalism movements. PROSHO indirectly helped stem the flow of radicalism (Nasih, FGD, October 10, 2018). The existence of a community where someone associates will influence his thoughts, attitudes, and actions. The alumni (i.e. Lirboyo Islamic boarding school) were supposed to be more careful in choosing the community (Atoilah Anwar, interview November 10, 2018).

$\mathrm{KH}$ Atoilah Anwar reminded the Lirboyo Islamic boarding school alumni to be wiser in choosing the salawat assembly. He directed to choose the prayer assembly following the attitude of the elder Kyai. He stressed that the prayer room assembly was good but there was an impact when he chose 
the salawat assembly. The alumni were also asked to be wiser in responding to social media, not to receive information from the media before making confirmation immediately. They are also told not to blame other groups including the government. The insistence on the issuance is not because of the accusation, blame, or demonstration. They are supposed to follow the model of Kyai Mahrus Ali by giving the government input in polite ways.

PROSHO's existence is also associated with global issues for example on economic and ideological issues as Indonesia is faced with Chinese and Arab powers. On ideology, the entry of Arabization culture in Indonesia brings out a few Habaib never raised before. The external Habibs deliver a lecture with the Arabic references, not referring to the context of Indonesia. In this case, the emergence of Nusuntara Islam becomes vital. (Nadirin, FGD. October 10, 2018).

Nadirin emphasized that there are economic and idological issues entering Indonesia, the economic process came from China, while the issue of ideology originated from Arabic (puritanical Islam). On the issue of ideology, the emergence of formalism in religion is shown when the Islamic person is manifested by wearing a turban and robe, just like Arab culture. Then the truth is identified with Arabic culture and traditions. They thought that what is not in Arabic and done by Muslims in Indonesia is wrong, such as tahlil, salawatan, istihgasha and some other practices. He also reminded of the emergence of the Habaibs, whose background was not known. Some of them have a salawat assembly. The local community will easily accept the assembly led by the Habaibs because they use religious symbols in the form of turban and robes.

The steps taken by PROSHO on the dissemination of radical ideas in the salawat assembly are carried out using a persuasive approach. For example is by coming to the host (societal support), understanding and associating prayer groups with certain religious groups. This case occurred in Nganjuk district. People who are active in religious traditions in tahlil, istihgasha, and salawatan are not necessarily identical with nahdiyin. "So it was not the first to openly reject it, but it was the one who organized the recitation, prayer and istihgasha. It's more dangerous, and on average they are Habaib. Those who respect them are NU people" (Nadirin, FGD. October 10, 2018).

The problem faced is more difficult in overcoming radicalism. Dealing with people involved in the movement is easy but it is precisely difficult to confront the Habaib. Habaib is affiliated with the movement, through 
assemblies, prayer boards, istihgasha, etc (Ibrahim Hafid, FGD. October 10, 2018). PROSHO activists realized that the Habaibs are descendants of the prophet who must be respected. On the other hand they are also faced with the reality of differences in perspectives in matters of thought, movement and piety.

PROSHO is also faced with FPI and its existing followers in the Mataraman region. Likewise with Ex-HTI in Mataraman region. Both have similarities with NU in their amaliyah affairs. For example, as delivered by Ibrahim Hafid: "Abu Somad, his fiqh is the same, the aqidah is the same, the Sufism is the same, but the syiah, the politics, the law are not the same. That is what is confronted with us, the NU Kyai who do not influence society" (Ibrahim Hafid, FGD. October 10, 2018).

The functional structural theory asserts that society is a social system consisting of interrelated and balanced parts or elements. Changes that occur in one section will also bring change to another part. In extreme adherence to this theory assumes that all events and all structures function for society. Accordingly, if there is a conflict, focus on how to solve it so that the community stays balanced. Society in functional theory is always in a changing state gradually while maintaining balance: every event and every functional structure for a social system (Merton 1968). Then, changes that occur in one part will cause an imbalance and make changes in another part (Parsons et al., 2001).

The movement carried out by PROSHO was not open by carrying out resistance but was only limited to establishing relations with the Rotib and Salawat assemblies. It is called a cultural movement that does not make direct contact with groups seen as rivals. This movement is commonly used by ulama in Mataraman when dealing with larger groups to avoid clashes with other groups.

\section{Dimensions of Person Religiosity}

Various approaches and perspectives show that religiosity's real dimension has not been agreed upon(Osafo et al. 2013:488; Pargament 1999:3). Religion is called the type of social system. This is to explain that religion is a social phenomenon, a social event. A social system can be analyzed, because it consists of complicated rules and regulations that are made interrelated and directed to a specific goal.

Studying religiosity can be seen from five dimensions of religiosity. First, the dimensions of ideology or belief, namely the dimensions of diversity, related 
to what must be believed, such as believing in God's existence, angels, heaven, and others. Religious beliefs or doctrines are the most basic dimensions. Second, the dimension of worship, namely the dimension of diversity related to a number of behaviors, where the behavior has been determined by religion, such as the procedures for worship, baptism, confession, fasting, prayer or carrying out special rituals on holy days. Third, the dimension of rewards, namely dimensions relating to religious feelings experienced by the followers or how far one can experience religious rituals, for example praying. Fourth, the dimension of knowledge is related to one's understanding and knowledge of the religious teachings. Fifth, the practice dimension, which is related to the consequences of the religious teaching applied through attitudes and behaviors in everyday life (Stark and Glock 1993).

HTI is religious, but it causes a lot of conflicts, which is dangerous. It actually causes riots which should be questioned. This is not a true religion, it is only a religion at a certain level. In NU, the higher the degree of relegation, the more open the thinking (Halim Bustomi, interview. November 10, 2018). The measure of religiosity is not based on one's appearance. Indeed, religiosity can be manifested in thinking that someone shows realized in the form of speech and action. High religiosity can be realized in the form of tolerance, openness, mutual respect for differences and not cause anxiety in society.

\section{Religious Traditions as a Form of Religiosity and Prevention of Radicalism}

Sholawatan as an embodiment of nahdliyin culture, is a filter to protect people from radicalism and terrorism. Terrorists are often reported as closed people and rarely associate with the community. They are rarely involved in ubudiyah muamalah (social worship) such as salawatan, tahlilan or religious ceremonies wrapped in culture. Groups that often pray for the tahlilan tradition and others are vulnerable to becoming radical Muslims and launch acts of terror.

There are three stages of violence. First, doctrinal violence, namely the literal understanding of religious texts and only accepting unilateral truths. Second, tradition and cultural violence. This is the effect of doctrinal violence making them unable to understand other different truths. Third, sociological violence, is an anarchic and destructive action against other parties accused of being musyrik, apostates and infidels (Wahid, 2009). 
The act of terrorism is classified in sociological violence, as the culmination of violence; terrorism will find cultural damage and loss of life together. The people's fears became unavoidable, with the loss of security in places of worship and public spaces affiliated as foreign property. The prayer can effectively prevent the perpetrators from radicalism and terrorism. This tradition has taken root in the nahdliyin people. In rural and urban areas. There is no need to question the legality of the religious traditions and the practices of NU.

Javanese believe that every Islamic tradition is by the Qur'an and sunnah, even though they do not know the verses and hadith. Laymen see it as a good thing, then nurtured. As a culture, religious traditions show the narrative of cosmopolitanism, namely nahdliyin. All people are invited, whether he is a santri or abangan Muslim, performs prayer or not, by diligently worshiping in a mosque or mushalla (Möller, 2005).

In the religious tradition, people also discuss any issues: agriculture, society, village government, and national political issues. The community builds social cohesion to connect with each other, understand problems, and find solutions. The organic religious tradition has become a counter-culture to prevent the growth of radicalism in society. It becomes social capital that gives the community cultural norms and values.

Social capital has four values. First, universalism, namely the value of others, appreciation, tolerance, and humans' protection as God's creation. Second, virtue, which is the value of maintaining and improving the welfare of others. Third, tradition, namely the value that contains appreciation, commitment, and acceptance of traditional cultural traditions and ideas. And fourth, conformity, values related to self-control to the urge to act that harm others, and security values that contain safety, harmony, stability in dealing with others and enforcing oneself.

\section{Conclusion}

The religious tradition in the Mataraman region is a manifestation of high community religiosity. The attitude of a person's religiosity can be manifested in religious rituals as the acculturation between the teachings of the religion and the culture, such as tahlilan, salawatan, istihgasha and others. Religious traditions that continue to be preserved in the society can strengthen solidarity. Public openness to tradition and culture will close the space for radicalization in society. Religious traditions in the community become a 
barrier to the flow of radicalism. The stronger a religious tradition is carried out by society, the more they move away from radical actions.

This tradition often gets opposition from radical Islamic groups who regard it as a trial of heresy and sin. As long as people still practice religious traditions so the radical religious groups do not dare to appear before the people in Mataraman region, because the community will directly refuse. With a strong pattern of relations between the people, they will likely close the entry of radical ideas in the Mataraman region.

However, lately religious traditions have also been utilized by those affiliated with radical groups through the salawat assembly (Majelis Ratib and Salawat), and the attendees received responses from other salawat groups (Pro Salawat). The presence of Pro Salawat is a counterweight to the entry of radical ideas through the salawat assembly. The process is carried out through a persuasive approach by reminding kyai, ustadh and alumni Islamic boarding schools to choose a prayer room assembly that has mainstream feelings with Muslims in the Mataraman region.

\section{References}

Al-Zastrouw. 2006. Gerakan Islam Simbolik ; Politik Kepentingan FPI. Lkis Pelangi Aksara.

Aviyah, E. and Farid, M. 2014. Religiusitas, Kontrol Diri dan Kenakalan Remaja. Persona: Jurnal Psikologi Indonesia 3(2), 126-129.

Dewan Pimpinan Pusat Front Pembela Islam. 2014. Maklumat FPI Tentang ISIS.

Fuad, A. J. 2018. Gerakan Kultural dan Pemberdayaan: Sebuah imun atas radikalisasi di Sanggar Sekar Jagad di Sukoharjo." Al-Tahrir: Jurnal Pemikiran Islam 18(1), 1-22.

Fuad, A. J. 2019. Tlatah dan Tradisi Keagamaan Islam Mataraman. Jurnal Pemikiran Keislaman 30(1), 1-27.

Fuad, A. J, and Susilo, S. 2019. Mainstreaming of Islamic Moderation in Higher Education: The radical experience center. Proceedings of Annual Conference for Muslim Scholars 3(1), 67-483.

Hill, P. C., and Kenneth, I. Pargament,. 2016. Advances in the Conceptualization and Measurement of Religion and Spirituality: Implications for physical and mental health research. Psychology of Religion and Spirituality 5(1), 3-17. 
Hood, R. W., Hill, P. C. and Spilka, B. 2009. The Psychology of Religion: An empirical approach. Guilford Press.

Indra, R. 2017. Wahabism: Padri Movement in Minangkabau to The Islamic Defender Organization in Indonesia. Researchers World: Journal of Arts, Science and Commerce 8(2), 79-91.

Klanjšek, R., Alexander T. V., and Trejos-Castillo, E. 2012. Religious Orientation, Low Self-Control, and Deviance: Muslims, Catholics, Eastern Orthodox-, and 'Bible Belt' Christians. Journal of Adolescence 35(3), 671-82.

Koenig, H. G., and Larson, D.B. 2001. Religion and Mental Health: Evidence for an association. International Review of Psychiatry 13(2), 67-78.

Mahdi, I. 2017. Pembubaran ORMAS 'Radikal' dalam Perspektif PerundangUndangan (Kajian khusus Perppu No. 02 Tahun 2017). Nuansa 10(2), $132-44$.

Mahzumi, M. A. A. S, and Fuad, A. J. 2019. Spiritual Education through Ziarah Tradition in Syaikh Syamsuddin Al-Wasil Kediri. El Harakah 21(2), 237-254.

Merton, R. K. 1968. Social Theory and Social Structure. Simon and Schuster.

Möller, A. 2005. Islam and Traweh Prayers in Java: Unity, diversity, and cultural smoothness. Indonesia and the Malay World 33(95), 37-52.

Mubarok, H. 2010. Memahami Kembali Arti Keragaman: Dimensi eksistensial, sosial dan institusional. Harmoni: Jurnal Multikultural $\mathcal{E}$ Multireligius 9(35), 32-45.

Nisya, L. S., and Sofiah, D. 2012. Religiusitas, Kecerdasan Emosional dan Kenakalan Remaja. Jurnal Psikologi Tabularasa 7(2), 562-584.

Osafo, J., Knizek, B. L. Akotia, C. S. and Hjelmeland, H. 2013. Influence of Religious Factors on Attitudes towards Suicidal Behaviour in Ghana. Journal of Religion and Health 52(2), 488-504.

Pargament, K. I. 1999. The Psychology of Religion and Spirituality? Yes and No. The International Journal for the Psychology of Religion 9(1), 3-16.

Parsons, T., Shils, E.A. and Smelser, N. J. 2001. Toward a General Theory of Action: Theoretical Foundations for the Social Sciences. Transaction Publishers.

el Harakah Jurnal Budaya Islam Vol. 22 No. 2 Tahun 2020 
Pertiwi, D.P.Y. and Chrisharyanto, H. 2016. Hubungan antara Religiusitas dengan Sikap terhadap Perilaku Teror pada Narapidana Kasus Terorisme di Indonesia. Jurnal SosioHumaniora 5(1), 23-43.

Rizki, M.F. 2018. Deradikalisasi Pengikut Hizbut Tahrir Indonesia Pasca Terbitnya Perppu No.2 Tahun 2017 tentang Ormas. Jurnal Politikom Indonesia 3(1), 164-176.

Saputri, A. and Rachmatan, R. 2017. Religiusitas dengan Gaya Hidup Hedonisme: Sebuah gambaran pada mahasiswa Universitas Syiah Kuala. Jurnal Psikologi 12(2):59-67.

Stark, R. and Glock, C.Y. 1993. Dimensi-Dimensi Keberagamaan dalam Agama dalam Analisa dan Interpretasi Sosiologis. Raja Grafindo Persada.

Syaefudin, M. 2014. Reinterpretasi Gerakan Dakwah Front Pembela Islam (FPI). Jurnal Ilmu Dakwah 34(2), 259-276.

Wahid, A. 2009. Ilusi Negara Islam-Ekspansi Gerakan Islam Transnasional di Indonesia. The Wahid Institute. 